\title{
Analisis Produk Deposito Mudharabah dan Penerapannya pada PT BPRS Amanah Ummah
}

\section{An Analysis of Mudaraba Fixed Deposits Account at PT BPRS Amanah Ummah}

\author{
${ }^{1}$ Siti Afifah, ${ }^{2}$ Ahmad Sobari, ${ }^{3}$ Hilman Hakiem \\ ${ }^{1}$ Alumnus Program Studi Ekonomi Syari'ah Fakultas Agama Islam, Universitas Ibn Khaldun Bogor \\ ${ }^{2}$ Dekan Fakultas Agama Islam, Universitas Ibn Khaldun Bogor \\ ${ }^{3}$ Ketua Program Studi Ekonomi Syari'ah Fakultas Agama Islam, Universitas Ibn Khaldun Bogor
}

\begin{abstract}
This paper attempts to analise the mudarabah fixed deposits product and its implementation in PT BPRS Amanah Ummah. This paper also tries to analise the nisbah examination on profit and loss sharing.The method used in this study is descriptive method. Fixed deposits account in PT BPRS Amanah Ummah has been known for its transaction using mudaraba contract. The contract, basically, involves two parties which have been working together as an investor (shahibul maal) and entrepreneur (mudharib) throughout the contract period. Bank has its own responsibility as the entrepreneur. The profit and loss are shared between them as stated in the contract and has been agreed by all involved parties. The proportion is indeed appeared as the result of bargaining process prior to the final agreement between them. If any loss occurred, the investor is the one who responsible on it. The entrepreneur is 'only' burdened on time and management loss. However, the situation may differ if the loss is caused by human error (the entrepreneur).
\end{abstract}

\section{Keywords. Mudarabah fixed deposits, PT BPRS Amanah Ummah}

Abstrak.Tulisan ini bertujuan untuk menganalisis produk deposito mudharabah dan penerapannya pada PT BPRS Amanah Ummah dan untuk menganalisis penentuan nisbah bagi hasil pada produk deposito PT BPRS Amanah Ummah. Metode yang digunakan dalam penelitian ini adalah metode deskriptif. Transaksi deposito mudharabah di PT BPRS Amanah Ummah menggunakan akad bagi hasil mudharabah, yaitu akad kerjasama usaha antara dua pihak di mana pihak pertama adalah nasabah yang berperan sebagai pemilik modal (shahibul maal), sedangkan pihak kedua adalah bank yang berperan sebagai pengelola modal (mudharib). Besarnya nisbah bagi hasil ditentukan berdasarkan kesepakatan masing-masing pihak yang berkontrak.Jadi, angka besaran nisbah ini muncul sebagai hasil tawar-menawar antara shahibul maal dengan mudharib. Dalam sistem tersebut terdapat risiko atas kerugian yang sewaktu-waktu dapat ditimbulkan. Apabila terdapat kerugian finansial/material, hanya pemilik modal yang menanggung kerugian tersebut. Selain itu pengelola dana hanya menanggung kerugian waktu dan tenaga dari apa yang telah diusahakannya, kecuali mudharib (dalam hal ini bank sebagai pengelola dana) lalai dalam melaksanakan tugasnya.

Kata Kunci. Penerapan deposito mudharabah, PT BPRS Amanah Ummah 


\section{Pendahuluan}

\subsection{Latar Belakang}

Perbankan syariah mengalami kemajuan yang sangat pesat. Keberadaannya telah mulai menjamur di mana-mana di seluruh wilayah Indonesia. Kesuksesan perbankan syariah diikuti oleh beberapa lembaga keuangan syariah lainnya, misalnya pegadaian syariah, asuransi syariah, dan BMT atau koperasi syariah. Lembaga keuangan syariah mempunyai karakteristik, seperti tidak memungut bunga dalam berbagai bentuk, menetapkan uang sebagai alat tukar bukan sebagai komoditas yang diperdagangkan, dan melakukan bisnis atau kerjasama untuk memperoleh imbalan dan bagi hasil. ${ }^{1}$

Harta atau modal tidak boleh menghasilkan dari dirinya sendiri, tetapi harus dengan usaha manusia.Ini salah satu sebab mengapa membungakan uang dalam bentuk riba dilarang oleh AlQur'an. Salah satu hikmah pelarangan riba, serta pengenaan zakat adalah untuk mendorong aktifitas ekonomi, perputaran dana serta sekaligus mengurangi spekulasi serta penimbunan ${ }^{2}$. Dalam hal ini Al-Qur'an mengingatkan:

"Wahai orang-orang yang beriman, sesungguhnya banyak dari orang-orang alim dan rahibrahib mereka benar-benar memakan harta orang dengan jalan batil, dan (mereka) menghalang-halangi (manusia) dari jalan Allah. Dan orang-orang yang menyimpan emas dan perak dan tidak menafkahkannya di jalan Allah, Maka berikanlah kabar gembira kepada mereka, (bahwa mereka akan mendapat) azab yang pedih". (Qs At-Taubah: 34). ${ }^{3}$

Selain giro dan tabungan, produk perbankan syariah lainnya yang termasuk produk penghimpun dana (funding) adalah deposito. Berdasarkan Undang-Undang Nomor 10 Tahun 1998 tentang Perubahan Atas Undang-Undang Nomor 7 Tahun 1992 tentang Perbankan, yang dimaksud dengan deposito berjangka adalah simpanan yang penarikannya hanya dapat dilakukan pada waktu-waktu tertentu menurut perjanjian antara penyimpanan dengan bank yang bersangkutan. ${ }^{4}$ Berdasarkan Undang-Undang Nomor 21 tahun 2008 tentang Perbankan Syariah, yang dimaksud dengan deposito adalah investasi dana berdasarkan akad mudharabah atau akad lain yang tidak bertentangan dengan prinsip syariah yang penarikannya hanya dapat dilakukan pada waktu tertentu berdasarkan akad antara nasabah penyimpan dan bank syariah dan/atau UUS. ${ }^{5}$

Adapun yang dimaksud dengan deposito syariah adalah deposito yang dijalankan berdasarkan prinsip syariah. Dalam hal ini, Dewan Syariah Nasional MUI telah mengeluarkan fatwa yang menyatakan bahwa deposito yang dibenarkan adalah deposito yang berdasarkan prinsip mudharabah, ${ }^{6}$ di mana bank syariah bertindak sebagai mudharib (pengelola dana) sedangkan nasabah bertindak sebagai shahibul maal (pemilik dana) dalam kapasitasnya sebagai mudharib, Bank syariah dapat melakukan berbagai macam usaha yang tidak bertentangan dengan prinsip syariah serta mengembangkannya, bank syariah akan membagihasilkan kepada pemilik dana atau pemilik deposito sesuai dengan nisbah yang telah disepakati dan telah dituangkan dalam akad.

Dengan demikian, bank syariah dalam kapasitasnya sebagai pengelola dana(mudharib) harus berhati-hati dan bertanggung jawab atas segala sesuatu yang timbul akibat kesalahan atau

\footnotetext{
${ }^{1}$ Muhammad Heykal, Nurul Huda, Lembaga Keuangan Islam Tinjauan Teoritis dan Praktis, Jakarta: Kencana Prenada Media Group,2010, h..276

${ }^{2}$ M. Quraish Shihab, Wawasan Al-Qur'an: Tafsir Maudhu'i Atas Berbagai Persoalan Umat, Jakarta: Mizan, 1996, h..403

${ }^{3}$ Al-Qur'an dan Terjemah, Jakarta: Pustaka Alfatih, 2009, h..192

${ }^{4}$ Adiwarman A.Karim, Bank Islam dan Analisis Fiqih dan Keuangan, Jakarta: PT Rajagrafindo Persada, 2004, h..303

${ }^{5}$ Undang-Undang Republik Indonesia No.21 Tahun 2008 Tentang Perbankan Syariah

${ }^{6}$ Fatwa Dewan Syariah Nasional No.03/DSN-MUI/IV/2000
} 
kelalaiannya, karena bank syariah bertindak sebagai kuasa dari usaha bisnis/proyek pemilik dana yang diharapkan dapat memperoleh keuntungan tanpa melanggar batas syariah.

Dalam menginvestasikan dana depositonya pada bank syariah, nasabah memiliki beragam tujuan, seperti untuk berjaga-jaga terhadap ketidakpastian yang akan datang, untuk persiapan pembelian suatu barang konsumsi di masa depan, ataupun untuk mengakumulasikan kekayaannya.

Mendepositokan uang di bank syariah cukup menarik karena dengan sistem bagi hasil, di mana perbankan syariah menekankan pada profit sharing, dengan pengertian bahwa simpanan yang ditabung atau didepositokan pada bank syariah nantinya akan digunakan untuk pembiayaan ke sektor riil oleh bank syariah, kemudian hasil atau keuntungan yang didapat akan dibagi menurut nisbah yang disepakati bersama. Jika keuntungan yang didapat besar, maka bagi hasil yang didapat juga besar. Berbeda dengan bank konvensional yang menerapkan sistem bunga dalam pengambilan keuntungannya, sehingga keuntungan yang didapat oleh para nasabahnya pun bersifat tetap tanpa mempedulikan apakah bank tersebut memperoleh keuntungan besar ataupun kecil. Akan tetapi, walaupun kemungkinan risikonya cukup besar, banyak anggota masyarakat yang menjadikan bank syariah sebagai ladang bisnis yang menggiurkan dan lebih berminat untuk mendepositokan dananya pada bank syariah yang dikarenakan tingkat keuntungan dari dana yang diinvestasikan lebih besar.

PT BPRS Amanah Ummah adalah salah satu bank syariah yang tumbuh di Indonesia khususnya wilayah Bogor Barat yang beroperasi berdasarkan prinsip-prinsip syariah Islam, yang bertujuan di antaranya menumbuhkan ekonomi masyarakat atas dasar syariah Islam. PT BPRS Amanah Ummah sebagai bank syariah juga mempunyai produk-produk penghimpunan dana, salah satunya yaitu deposito mudharabah di mana peranannya menjadi salah satu alternatif pemenuhan kebutuhan investasi masyarakat.

Berdasarkan fenomena tersebut, maka diperlukan suatu kajian yang mendalam untuk mengetahui bagaimana penerapan fikih muamalah terhadap produk deposito pada bank syariah.

\subsection{Perumusan dan Pembatasan Masalah}

\subsubsection{Perumusan Masalah}

Berdasarkan latar belakang tersebut, maka permasalahan yang akan di ajukan oleh penulis adalah:

1. Bagaimanakah analisis produk deposito mudharabah dan penerapannya pada PT BPRS Amanah Ummah?

2. Bagaimanakah analisis penentuan nisbah bagi hasil pada produk deposito PT BPRS Amanah Ummah?

\subsubsection{Pembatasan Masalah}

Berdasarkan perumusan masalah diatas maka penulis akan membatasi permasalahan tentang "Analisis Produk Deposito Mudharabah dan Penerapannya pada PT BPRS Amanah Ummah" 


\subsection{Tujuan dan Kegunaan Penelitian}

\subsubsection{Tujuan Penelitian}

Tujuan dari masalah yang dirumuskan oleh penulis diatas adalah:

1. Untuk menganalisis produk deposito mudharabah dan penerapannya pada PT BPRS Amanah Ummah.

2. Untuk menganalisis penentuan nisbah bagi hasil pada produk deposito PT BPRS Amanah Ummah.

\section{Metode, Jenis dan Teknik Penelitian}

\subsection{Penelitian}

Dengan melihat permasalahan penelitian, maka metode yang digunakan adalah metode deskriptif. Metode deskriptif dirancang untuk mengumpulkan informasi tentang keadaankeadaan nyata sekarang (sementara berlangsung) ${ }^{7}$.

\subsection{Jenis Penelitian}

Jenis penelitian yang digunakan oleh penulis untuk penelitian ini adalah penelitian lapangan, di mana penulis langsung meneliti di bagian yang menangani deposito syariah pada PT BPRS Amanah Ummah.

\subsection{Teknik Penelitian}

Di dalam mengumpulkan data sangat dibutuhkan adanya teknik yang tepat dan relevan dengan jenis data yang diperlukan. Adapun data yang diperlukan dalam penelitian ini diperoleh melalui cara:

1. Pengumpulan data

2. Studi Pustaka

Dilakukan dengan cara mengkaji dan menelaah buku-buku, karya ilmiah, makalahmakalah, jurnal, majalah yang berkaitan dengan judul skripsi tersebut.

3. Observasi (Pengamatan)

Observasi diartikan sebagai suatu pengamatan terhadap objek penelitian ${ }^{8}$. Dengan cara pengamatan dan penelitian lapangan secara langsung pada PT BPRS Amanah Ummah, guna memperoleh informasi sebagai pendukung data dalam penyusunan tulisan.

4. Interview (Wawancara)

Wawancara adalah pengumpulan data dengan bertanya jawab langsung ${ }^{9}$, baik secara lisan maupun tulisan. Pertanyaan yang diajukan telah dipersiapkan sebelumnya. Wawancara dilakukan terhadap manajer dan karyawan PT BPRS Amanah Ummah tentang masalah-masalah yang berkaitan dengan objek penelitian.

5. Dokumentasi

Dokumentasi adalah mengumpulkan data dengan cara mengalir atau mengambil datadata dari catatan, dokumentasi, administrasi yang sesuai dengan masalah yang diteliti. Dalam hal ini dokumentasi diperoleh melalui dokumen-dokumen atau arsip-arsip dari lembaga yang diteliti ${ }^{10}$.

\footnotetext{
${ }^{7}$ Consuelo G. Sevilla, Jesus A Ochave, Twila G.Punsalan, Bella P.regala, Gabriel G.Uriarte, Pengantar Metode Penelitian, Jakarta: Universitas Indonesia,1993,h..71

${ }^{8}$ Hendri Tanjung, Metodologi Penelitian, Bogor: UIKA Press, 2012, h..40

${ }^{9}$ Ibid, h...32

${ }^{10}$ Nasution, Metodologi Research Penelitian Ilmiah, Jakarta: Bumi Aksara, 2003, h..143
} 
6. Pengolahan dan Analisa data

Teknik pengolahan dan analisa data yang penulis gunakan adalah teknik deskriptif, di mana teknik deskriptif ini penulis dapat melihat langsung bagaimana penerapan fikih muamalah pada produk deposito yang ada di lapangan.

\section{Landasan Teori}

\section{Deposito}

\section{Pengertian Deposito}

Selain giro dan tabungan, produk perbankan syariah lainnya yang termasuk produk penghimpun dana (funding) adalah deposito. Berdasarkan Undang-Undang Nomor 10 Tahun 1998 tentang Perubahan Atas Undang-Undang Nomor 7 Tahun 1992 tentang Perbankan, yang dimaksud dengan deposito berjangka adalah simpanan yang penarikannya hanya dapat dilakukan pada waktu-waktu tertentu menurut perjanjian antara penyimpanan dengan bank yang bersangkutan. ${ }^{11}$

Penarikan hanya dapat dilakukan pada waktu tertentu maksudnya adalah jika nasabah deposan menyimpan uangnya untuk jangka waktu 3 bulan, maka uang tersebut baru dapat dicairkan setelah jangka waktu tersebut berakhir dan sering disebut tanggal jatuh tempo. Sebagai contoh, jika seorang deposan yang bernama Tn. Rahman Hakim mendepositokan uang tanggal 7 Mei 2002 untuk 3 bulan mendatang, maka tanggal jatuh temponya adalah setelah 3 bulan yaitu tanggal 7 Agustus 2002, dan apabila dicairkan sebelum tanggal tersebut maka si deposan akan dikenakan denda (penalty rate) yang besarnya tergantung dari bank yang bersangkutan. Dalam praktiknya saat ini ada bank yang tidak mengenakan penalty rate sekalipun ditarik sebelum jatuh tempo. Sarana atau alat untuk menarik uang yang disimpan di deposito sangat tergantung dari jenis depositonya. Artinya setiap jenis deposito mengandung beberapa perbedaan sehingga diperlukan sarana yang berbeda pula. Sebagai contoh, untuk deposito berjangka penarikannya menggunakan bilyet deposito, sedangkan untuk sertifikat deposito menggunakan sertifikat deposito. $^{12}$

Dengan kata lain, nasabah tidak dapat mencairkan depositonya sewaktu-waktu karena dalam deposito terdapat ketentuan-ketentuan dalam pencairan dana. Jika nasabah mendepositokan pada jangka waktu 3 bulan maka nasabah dapat mencairkan depositonya pada jangka waktu tersebut, dan apabila pada jangka waktu jatuh tempo nasabah tidak melakukan pencairan dana maka pihak bank secara otomatis akan memperpanjang deposito tersebut sampai 3 bulan berikutnya. Dalam praktiknya deposito yang ditawarkan terdiri dari beragam jenis, di antaranya deposito berjangka, sertifikat deposito dan deposit on call.

\section{Deposito Berjangka}

Deposito berjangka merupakan deposito yang diterbitkan menurut jangka waktu tertentu. Jangka waktu deposito biasanya bervariasi mulai dari 1, 2, 3, 6, 12, 18 sampai dengan 24 bulan. Deposito berjangka diterbitkan atas nama, baik perorangan maupun lembaga. Artinya di dalam bilyet deposito tercantum nama seseorang atau lembaga.

\footnotetext{
${ }^{11}$ Adiwarman A.Karim, Bank Islam dan Analisis Fiqih dan Keuangan, Jakarta: PT Rajagrafindo Persada, 2004 , h..303

${ }^{12}$ Kasmir, Dasar-Dasar Perbankan, Jakarta: PT Rajagrafindo Persada, 2002, h..93
} 


\section{Sertifikat Deposito}

Merupakan deposito yang diterbitkan dengan jangka waktu 2, 3, 6, dan 12 bulan. Sertifikat deposito diterbitkan atas unjuk dalam bentuk sertifikat. Artinya di dalam sertifikat deposito tidak tertulis nama seseorang atau badan hukum tertentu. Di samping itu, sertifikat deposito dapat diperjualbelikan pada pihak lain. Pencairan bunga sertifikat deposito dapat dilakukan di muka, tiap bulan atau jatuh tempo, baik tunai maupun non tunai. Dalam praktiknya kebanyakan deposan mengambil bunga di muka. Penerbit nilai sertifikat deposito sudah tercetak dalam berbagai nominal dan biasanya dalam jumlah bulat, sehingga nasabah dapat membeli dalam lembaran banyak untuk jumlah nominal yang sama.

\section{Deposit On Call}

Merupakan deposito yang berjangka waktu minimal 7 hari dan paling lama kurang dari 1 bulan. Diterbitkan atas nama dan biasanya dalam jumlah yang besar misalnya 50 juta rupiah (tergantung bank yang bersangkutan). Pencairan bunga dilakukan pada saat pencairan deposit on call dan sebelum deposit on call dicairkan terlebih dahulu 3 hari sebelumnya nasabah sudah memberitahukan bank penerbit. Besarnya bunga biasanya dihitung per bulan dan biasanya untuk menentukan bunga dilakukan negosiasi antara nasabah dengan pihak bank. ${ }^{13}$

\section{Mudharabah}

\section{Pengertian Mudharabah}

Bank syariah dan konvensional sangat berbeda dari segi prinsip maupun produk-produk yang disediakannya. Bank syariah menganut prinsip bagi hasil dengan nasabahnya. Dari segi pembagian jenis produk-produk bank syariah sama seperti bank konvensional terbagi menjadi tiga jenis, yaitu penghimpun dana, penyaluran dana dan jasa perbankan.

1. Penghimpun dana

Wadi'ah, suatu produk bank syariah di mana nasabah dapat menitipkan dananya ke bank, dan nasabah dapat menarik kembali dananya kapan saja.

Al-Mudarabah, suatu bentuk kerjasama antara dua pihak di mana pihak pertama sebagai pemberi modal dan pihak kedua sebagai pengelola. Keuntungan yang didapat akan dibagi sesuai kesepakatan. Sedangkan kerugian akan ditanggung oleh pemberi modal selama kerugian tidak disebabkan oleh kelalaian pengelola. Jika kerugian disebabkan kelalaian dan kecurangan pengelola, maka kerugian akan ditanggung oleh pengelola.

Al-Musyarakah, konsep ini seperti partnership di mana terdapat dua pihak atau lebih yang saling mengumpulkan dananya untuk mendirikan suatu usaha. Keuntungan dan kerugian dari usaha akan ditanggung bersama sesuai kesepakatan.

2. Penyaluran dana

Bai' Al-Murabahah, transaksi jual beli di mana bank sebagai pihak penjual memberikan harga berdasarkan harga perolehan ditambah keuntungan yang sudah disepakati dengan nasabah sebagai pihak pembeli. Nasabah dapat mengangsur pembayaran kepada bank.

Bai' As-Salam, transaksi jual beli dimana pembayaran dilakukan di muka sedangkan barang dagang akan dikirim pada waktu yang disepakati. Setelah barang dikirim, bank selaku pembeli dapat menjual kembali.

Bai' Al-Istishna, Istishna secara bahasa berarti pemesanan. Bank sebagai pemesan memesan barang kepada nasabah sebagai penjual atau pembuat. Secara berangsur bank membayar sesuai prinsif Bai' Al-Istishna. Setelah barang selesai dibuat, bank dapat menjual kembali.

3. Jasa perbankan

Kafalah, menurut Bank Indonesia (1999) kafalah adalah akad pemberian jaminan yang diberikan suatu pihak kepada pihak lain di mana pemberi jaminan bertanggung jawab atas pembayaran kembali suatu utang yang menjadi hak penerima jaminan.

\footnotetext{
${ }^{13}$ Ibid, h.. 98
} 
Hawalah, pengalihan piutang di mana jika nasabah memiliki utang kepada bank dan piutang kepada pihak lain dalam jumlah yang sama, maka nasabah dapat mengalihkan pinjaman dari bank ke pihak lain tersebut.

Rahn, pemberian pinjaman kepada nasabah di mana nasabah memberikan harta benda yang senilai dengan besarnya pinjaman sebagai jaminan. Prinsip ini seperti gadai.

Walakah, adalah prinsif perwakilan, di mana nasabah memberikan kuasa atas kegiatan perbankan yang tidak dapat ia lakukan, seperti transfer dana, penagihan letter of credit, inkaso, dan lain-lain. Sebagai imbalan, bank mendapatkan fee.

Dalam hal ini, penulis akan membahas salah satu produk perbankan syariah yaitu tentang mudharabah, di mana kata mudharabah berasal dari kata dharaba pada kalimat al-dharb fi alardh, yakni bepergian untuk urusan dagang. Secara bahasa, menurut Abdurrahman al-Jaziri, mudharabah berarti ungkapan terhadap pemberian harta dari seorang kepada orang lain sebagai modal usaha di mana keuntungan yang diperoleh akan dibagi di antara mereka berdua, dan bila rugi akan ditanggung oleh pemilik modal. ${ }^{14}$

Dalam UU No.21 Tahun 2008 tentang Perbankan Syariah, dijelaskan definisi tabungan sebagai simpanan berdasarkan akad wadi'ah atau investasi dana berdasarkan akad mudharabah atau akad lain yang tidak bertentangan dengan prinsip syariah yang penarikannya hanya dapat dilakukan menurut syarat dan ketentuan tertentu yang disepakati, tetapi tidak dapat ditarik dengan cek, bilyet giro, dan/atau alat lainnya yang dipersamakan dengan itu. ${ }^{15}$

Al-Mudharabah adalah akad perjanjian antara dua pihak atau lebih untuk melakukan kerja sama usaha. Satu pihak akan menempatkan modal sebesar $100 \%$ yang disebut dengan shahibul maal, dan pihak lainnya sebagai pengelola usaha, disebut dengan mudharib. Bagi hasil dari usaha yang dikerjasamakan dihitung sesuai dengan nisbah yang disepakati antara pihak-pihak yang bekerja sama. ${ }^{16}$

Secara muamalah, pemilik modal (shahibul maal) menyerahkan modalnya kepada pedagang/pengusaha (mudharib) untuk digunakan dalam aktifitas perdagangan atau usaha. Keuntungan atas usaha perdagangan yang dilakukan oleh mudharib itu akan dibagihasilkan dengan shahibul maal. Pembagian hasil usaha ini berdasarkan kesepakatan yang telah dituangkan dalam akad. ${ }^{17}$

Secara teori, kontrak mudharabah merupakan kontrak kemitraan antara investor, uang tersebut dalam bentuk yang dianggap sesuai oleh sang agen dengan kesepakatan pembagian keuntungan. Biasanya kontrak/akad ini dibatasi hingga jangka waktu tertentu yang menjadi waktu pembagian keuntungan yang disepakati. Contoh mudharabah pada masa modern adalah kontrak antar investor tersebut mendepositkan dana kepada bank Islam yang telah memiliki keahlian tertentu dalam pasar finansial dan mampu mengidentifikasi proyek yang menguntungkan serta mampu menggunakan keterampilan manajemennya untuk menginvestasikan uang investor. Setelah beberapa waktu tertentu, bank dan investor berbagi keuntungan berdasarkan rasio pembagian keuntungan yang telah ditetapkan sebelumnya. ${ }^{18}$

Salah satu ciri mudharabah paling penting adalah ketika keuntungan dibagi di antara investor dan agen, semua kerugian dalam investasi atau bisnis ditanggung oleh pemilik modal seorang diri, kecuali apabila kerugian tersebut disebabkan oleh tindakan yang tidak pantas atau kelalaian

\footnotetext{
${ }^{14}$ Helmi Karim, Fiqih Muamalah Cet 2, Jakarta: PT Rajagrafindo Persada, 1997, h..11

${ }^{15}$ Undang-Undang Republik Indonesia No.21 Tahun 2008 tentang Perbankan Syariah

${ }^{16}$ Ismail, Perbankan Syariah, Jakarta: Kencana Prenada Media Group, 2011, h..83

${ }^{17}$ Ibid, h..84

${ }^{18}$ Zamir Iqbal Abbas Mirakhor, Pengantar Keuangan Islam Teori dan Praktek, Jakarta: Kencana Prenada Media Group, 2008, h.. 130
} 
mudharib.Apabila tidak terjadi tindakan yang tidak pantas dan kelalaian, mudharib tersebut tidak bertanggung jawab atas segala kerugian dalam usahanya. Dalam kasus di mana agen bertindak dengan niat yang baik dan berhati-hati, tetapi investasi tersebut masih terus merugi, pemilik modal akan kehilangan bagian modalnya, akan tetapi sang agen juga akan kehilangan bagian modalnya, akan tetapi sang agen juga akan kehilangan waktu dan upaya yang dicurahkan dalam bisnis. Karena itu, baik investor maupun agen sama-sama menderita kerugian, hanya saja dalam cara yang berbeda. Pemilik modal menderita kerugian finansial akibat kehilangan modal, sedangkan sang agen tidak mendapatkan keuntungan finansial apapun, tetapi menderita kerugian potensi imbalan. Mudharib bukanlah penjamin modal tersebut, kecuali jika ada tindakan tidak pantas atau kelalaian dari pihaknya. ${ }^{19}$

Dari beberapa pengertian tersebut, dapat ditarik kesimpulan bahwa mudharabah adalah akad kerjasama usaha antara dua pihak di mana pihak pertama adalah nasabah yang berperan sebagai pemilik modal (shahibul maal), sedangkan pihak kedua adalah bank yang berperan sebagai pengelola modal (mudharib), dalam sistem tersebut terdapat risiko atas kerugian yang sewaktuwaktu dapat ditimbulkan. Apabila terdapat kerugian finansial/material hanya pemilik modal yang menanggung kerugian tersebut. Selain itu pengelola dana hanya menanggung kerugian waktu dan tenaga dari apa yang telah diusahakannya, kecuali mudharib (dalam hal ini bank sebagai pengelola dana) lalai dalam melaksanakan tugasnya.

\section{Tabungan Mudharabah}

Tabungan Mudharabah merupakan produk penghimpunan dana oleh bank syariah yang menggunakan akad mudharabah mutlaqah. Bank bertindak sebagai mudharib dan nasabah sebagai shahibul maal. Nasabah menyerahkan pengelolaan dana tabungan mudharabah secara mutlak kepada mudharib (bank syariah), tidak ada batasan baik dilihat dari jenis investasi, jangka waktu, maupun sektor usaha, dan tidak boleh bertentangan dengan prinsip syariah Islam.

Bank syariah akan membayar bagi hasil kepada nasabah setiap akhir bulan, sebesar sesuai dengan nisbah yang telah diperjanjikan pada saat pembukaan rekening tabungan mudharabah. Bagi hasil yang akan diterima nasabah akan selalu berubah pada akhir bulan. Perubahan bagi hasil ini disebabkan karena adanya fluktuasi pendapatan bank syariah dan fluktuasi dana tabungan nasabah.

Bagi hasil tabungan mudharabah sangat dipengaruhi oleh antara lain:

a. Pendapatan bank syariah

b. Total investasi mudharabah mutlaqah

c. Total investasi produk tabungan mudharabah

d. Rata-rata saldo tabungan mudharabah

e. Nisbah tabungan mudharabah yang ditetapkan sesuai dengan perjanjian

f. Metode perhitungan bagi hasil yang diberlakukan

g. Total pembiayaan bank syariah. ${ }^{20}$

Beberapa ketentuan umum tabungan mudharabah sebagai berikut:

a. Dalam transaksi ini, nasabah bertindak sebagai shahibul mal atau pengelola dana

b. Dalam kapasitasnya sebagai mudharib, bank dapat melakukan berbagai macam usaha yang tidak bertentangan dengan prinsip syari'ah dan mengembangkannya, termasuk di dalamnya mudharabah dengan pihak lain.

c. Modal harus dinyatakan dengan jumlahnya, dalam bentuk tunai dan bukan piutang

d. Pembagian keuntungan harus dinyatakan dalam bentuk nisbah dan dituangkan dalam bentuk akad pembukaan rekening

\footnotetext{
${ }^{19}$ Ibid, h..131

${ }^{20}$ Ismail, Perbankan Syariah, h..89
} 
e. Bank sebagai mudharib menutup biaya operasional tabungan dengan menggunakan nisbah keuntungan yang menjadi haknya

f. Bank tidak diperkenankan mengurangi nisbah keuntungan nasabah tanpa persetujuan yang bersangkutan. ${ }^{21}$

\section{Deposito Mudharabah}

\section{Pengertian Deposito Mudharabah}

Seperti halnya pada tabungan, dalam deposito mudharabah, nasabah deposan bertindak sebagai shahibul maal. Penerapan mudharabah dalam deposito dikarenakan kesesuaian yang telah ditetapkan di antara keduanya. ${ }^{22}$ Misalnya yang dikemukakan dalam akad mudharabah mensyaratkan adanya tenggang waktu antara penyetoran dan penarikan agar dana itu bisa diputarkan. Tenggang waktu itu merupakan sifat deposito, bahkan dalam deposito terdapat pengaturan waktu, seperti 30 hari, 90 hari, dan seterusnya. ${ }^{23}$

Perbedaan jangka waktu deposito berjangka di samping merupakan perbedaan masa penyimpanan, juga akan menimbulkan perbedaan balas jasa berupa besarnya persentase nisbah bagi hasil. Pada umumnya, semakin lama jangka waktu deposito berjangka, akan semakin tinggi persentase nisbah bagi hasil yang diberikan oleh bank syariah. ${ }^{24}$

Deposito biasanya terkait dengan pembungaan uang pada bank-bank konvensional. Namun di dalam bank syariah, yang disebut dengan deposito itu tentu bentuknya berbeda dengan yang ada di bank konvensional. Karena itu kemudian deposito itu disebut dengan deposito syariah. Artinya, deposito dilakukan berdasarkan konsep bagi hasil, bukan berdasarkan pembungaan uang yang mengandung riba. Bank syariah mempunyai produk deposito yang dijamin $100 \%$ aman dari riba. Sebab uang itu memang tidak ditanamkan dengan sistem bunga, melainkan sistem bagi hasil. Juga ada aturan bahwa bank syariah tersebut tidak dibenarkan menanamkan uang deposito pada institusi yang mempunyai produk haram, seperti pabrik minuman keras, narkoba, pabrik rokok atau produk-produk haram lainnya. ${ }^{25}$

Dengan demikian, pemutaran uang deposito tersebut tidak sampai melewati batas wilayah usaha yang tidak bersih atau haram. Apalagi di setiap bank syariah sudah dapat dipastikan adanya dewan pengawas syariah, di mana dewan tersebut terdiri dari pakar yang paham dengan hukum perbankan syariah.

\section{Penalti}

Penalti merupakan denda yang dibebankan kepada nasabah pemegang rekening deposito mudharabah apabila nasabah mencairkan depositonya sebelum jatuh tempo. Penalti ini dibebankan karena bank telah mengestimasikan penggunaan dana tersebut, sehingga pencairan deposito berjangka sebelum jatuh tempo dapat mengganggu likuiditas bank. Bank perlu membebankan penalti (denda) kepada setiap nasabah deposito berjangka yang menarik depositonya sebelum jatuh tempo. Penalti tidak boleh diakui sebagai pendapatan operasional bank syariah, akan tetapi digunakan untuk dana kebajikan, yang dimanfaatkan untuk membantu pihak-pihak yang membutuhkan.

\footnotetext{
${ }^{21}$ Adiwarman, Bank Islam, h..301

${ }^{22}$ Muhammad Syafi'i Antonio, Bank Syariah dari Teori ke Praktik, Jakarta: Gema Insani Press, 2001, h. 157

${ }^{23}$ Ibid, h.. 157

${ }^{24}$ Ismail, Perbankan, h..92

${ }^{25}$ Helmi Karim, Fiqih Muamalah Cet 2, Jakarta: PT Rajagrafindo Persada, 1997, h..27
} 
Penalti tidak dibebankan kepada setiap nasabah yang menarik depositonya sebelum jatuh tempo. Ada nasabah tertentu yang tidak dibebani penalti ketika menarik dananya yang berasal dari deposito berjangka yang belum jatuh tempo, misalnya nasabah prima (prime costumer), tidak dibebani penalti. Hal ini dimaksudkan untuk menarik nasabah dengan memberikan pelayanan prima kepada nasabah tertentu yang loyal kepada bank, yaitu bebas biaya penalti. ${ }^{26}$

\section{Landasan Hukum Deposito Mudharabah}

Dalam Islam akad mudharabah dibolehkan, karena bertujuan untuk saling membantu antara shahibul maal (investor) dengan pengelola dagang (mudharib). Demikian dikatakan oleh Ibn Rusyd (w.595/1198) dari madzhab Maliki bahwa kebolehan akad mudharabah merupakan suatu kelonggaran yang khusus.

Meskipun mudharabah tidak secara langsung disebutkan oleh Al-Qur'an atau Sunnah, ia adalah sebuah kebiasaan yang diakui dan dipraktikkan oleh umat Islam, dan bentuk dagang semacam ini tampaknya terus hidup sepanjang periode awal era Islam sebagai tulang punggung perdagangan karavan dan perdagangan jarak jauh. ${ }^{27}$

Beberapa dalil yang bias dijadikan landasan dibolehkannya praktik mudharabah, antara lain adalah:

1. QS. Al-Muzzammil ayat 20 :

“...dan orang-orang yang berjalan di muka bumi mencari sebagian karunia Allah...”.(QS.Al-Muzammil:20)

2. QS. Al-Baqarah ayat 198:

"Tidak ada dosa bagimu untuk mencari karunia (rezeki hasil perniagaan) dari Tuhanmu”. (QS. Al-Baqarah: 198)

3. QS. An-Nisa ayat 29

"Hai orang-orang yang beriman, janganlah kamu saling memakan harta sesamamu dengan jalan yang batil, kecuali dengan jalan perniagaan yang berlaku dengan suka sama-suka di antara kamu...."(QS. An-Nisa:29)

4. QS. Al-Maidah ayat 1

“Hai orang-orang yang beriman, penuhilah aqad-aqad itu..." (QS. Al-Maidah:1)

Ayat-ayat tersebut secara umum mengandung kebolehan akad mudharabah, yang secara bekerjasama mencari rezeki yang ditebarkan Allah SWT di muka bumi.

Sedangkan dalil yang bersumber dari hadis Nabi antara lain:

1. Hadis Nabi riwayat Thabrani

“Tuan kami 'Abbas Ibn Abd al-Muthalib' jika menyerahkan hartanya (kepada seorang yang pakar dalam perdagangan) melalui akad mudharabah, dia mengemukakan syarat bahwa harta itu jangan diperdagangkan melalui lautan, juga jangan menempuh lembah-lembah, dan tidak boleh dibelikan hewan ternak yang sakit tidak dapat bergerak atau berjalan. Jika (ketiga) hal itu dilakukan, maka pengelola modal dikenai

\footnotetext{
${ }^{26}$ Ibid, h..95

${ }^{27}$ http://halal-ok.blogspot.com/2009/10/tinjauan-syariah-produk-deposito.html, diakses pada tanggal 10 Juni 2013
} 
ganti rugi. Kemudian syarat yang dikemukakan Abbas Ibn Abd al-Muthalib ini sampai kepada Rasulullah SAW, dan Rasul membolehkannya”. (HR. Ath-Tabrani)

2. Hadis Nabi riwayat Ibnu Majah

"Nabi bersabda, 'Ada tiga hal yang mengandung berkah: jual beli tidak secara tunai, muqaradhah (mudharabah), dan mencampur gandum dengan jewawut untuk keperluan rumah tangga, bukan untuk dijual." (HR. Ibnu Majah dari Shuhaib).

3. Hadis Nabi riwayat Tirmidzi

"Perdamaian dapat dilakukan di antara kaum muslimin kecuali perdamaian yang mengharamkan yang halal atau menghalalkan yang haram; dan kaum muslimin terikat dengan syarat-syarat mereka kecuali syarat yang mengharamkan yang halal atau menghalalkan yang haram" (HR. Tirmidzi dari 'Amr bin 'Auf).

\section{Rukun dan Syarat Mudharabah}

Rukun dan Syarat dalam akad Mudharabah adalah:

1) Adanya dua pelaku atau lebih, yaitu investor (pemilik modal) dan pengelola (mudharib). Kedua belah pihak yang melakukan akad disyaratkan mampu melakukan tasharruf atau cakap hukum, maka dibatalkan akad anak-anak yang masih kecil, orang gila, dan orangorang yang berada di bawah pengampuan.

2) Modal atau harta pokok (mal), syarat-syaratnya yakni:

a. Berbentuk uang

Mayoritas ulama berpendapat bahwa modal harus berupa uang dan tidak boleh barang. Mudharabah dengan barang dapat menimbulkan kesamaran, karena barang pada umumnya bersifat fluktuatif. Apabila barang itu bersifat tidak fluktuatif seperti berbentuk emas atau perak batangan (tabar), para ulama berbeda pendapat. Imam Malik dalam hal ini tidak tegas melarang atau membolehkan. Namun para ulama mazhab Hanafi membolehkannya dan nilai barang yang dijadikan setoran modal harus disepakati pada saat akad oleh mudharib dan shahibul maal. Contohnya, seorang memiliki sebuah mobil yang akan diserahkan kepada mudharib (pengelola modal). Ketika akad kerja sama tersebut disepakati, maka modal tersebut wajib ditentukan nilai mata uang saat itu, misalnya Rp 90.000.000, maka modal mudharabah tersebut adalah Rp 90.000.000.

b. Jelas jumlah dan jenisnya

Jumlah modal harus diketahui dengan jelas agar dapat dibedakan antara modal yang diperdagangkan dengan laba atau keuntungan dari perdagangan tersebut yang akan dibagikan kepada dua belah pihak sesuai dengan perjanjian yang telah disepakati.

c. Tunai

Utang tidak dapat dijadikan modal mudharabah. Tanpa adanya setoran modal, berarti shahibul maal tidak memberikan kontribusi apapun padahal mudharib telah bekerja. Para ulama Syafi'i dan Maliki melarang hal itu karena merusak sahnya akad. Selain itu hal ini bisa membuka pintu perbuatan riba, yaitu memberi tangguh kepada si berutang yang belum mampu membayar utangnya dengan kompensasi si berpiutang mendapatkan imbalan tertentu. Dalam hal ini para ulama fiqih tidak berbeda pendapat.

d. Modal diserahkan sepenuhnya kepada pengelola secara langsung

Apabila tidak diserahkan kepada mudharib secara langsung dan tidak diserahkan sepenuhnya (berangsur-angsur) dikhawatirkan akan terjadi kerusakan pada modal, yaitu 
penundaan yang dapat mengganggu waktu mulai bekerja dan akibat yang lebih jauh yaitu mengurangi kerjanya secara maksimal. Apabila modal itu tetap dipegang sebagiannya oleh pemilik modal, dalam artian tidak diserahkan sepenuhnya, maka menurut ulama Hanafiyah, Malikiyah, dan Syafi'iyah, akad mudharabah tidak sah. Sedangkan ulama Hanabilah menyatakan boleh saja sebagian modal itu berada di tangan pemilik modal, asal tidak mengganggu kelancaran usahanya.

3) Keuntungan, syarat-syaratnya yakni:

a. Proporsi jelas. Keuntungan yang akan menjadi milik pengelola dan pemilik modal harus jelas persentasenya, seperti 60\%:40\%, 50\%: $0 \%$ dan sebagainya menurut kesepakatan bersama.

b. Keuntungan harus dibagi untuk kedua belah pihak, yaitu investor (pemilik modal) dan pengelola (mudharib).

c. Break Even Point (BEP) harus jelas, karena BEP menggunakan sistem revenue sharing dengan profit sharing berbeda. Revenue sharing adalah pembagian keuntungan yang dilakukan sebelum dipotong biaya operasional, sehingga bagi hasil dihitung dari keuntungan kotor/pendapatan. Sedangkan profit sharing adalah pembagian keuntungan dilakukan setelah dipotong biaya operasional, sehingga bagi hasil dihitung dari keuntungan bersih.

4) Ijab Qabul

Melafazkan ijab dari pemilik modal, misalnya aku serahkan uang ini kepadamu untuk dagang jika ada keuntungan akan dibagi dua dan qabul dari pengelola. ${ }^{28}$

\section{Bentuk Mudharabah}

Berdasarkan kewenangan yang diberikan oleh pihak pemilik dana, terdapat dua bentuk mudharabah, yakni:

\section{a. Mudharabah Mutlaqah (Unresticted Investment Account, URIA)}

Dalam deposito Mudharabah Muthlaqah (URIA), pemilik dana tidak memberikan batasan atau persyaratan tertentu kepada bank syariah dalam mengelola investasinya. Dengan kata lain, bank syariah mempunyai hak dan kebebasan sepenuhnya dalam menginvestasikan dana URIA ini ke berbagai sektor bisnis yang diperkirakan akan memperoleh keuntungan. ${ }^{29}$

Pihak pengelola dana (bank sebagai mudharib) diberi kuasa penuh untuk menjalankan suatu usaha atau proyek oleh pemilik dana (shahibul maal) tanpa larangan atau gangguan apapun urusan yang berkaitan dengan proyek tersebut, dan apabila terjadi kerugian pengelola dana yang bukan disebabkan kelalaian atau kesalahan bank sebagai mudharib, maka kerugian ditanggung oleh pemilik dana (shahibul maal).

\section{b. Mudharabah Muqayyadah (Restricted Investment Account, RIA)}

Berbeda halnya dengan deposito Mudharabah Mutlaqah (URIA), dalam deposito Mudharabah Muqayyadah (RIA), pemilik dana memberikan batasan atau persyaratan tertentu kepada bank syariah dalam mengelola investasinya, baik yang berkaitan dengan tempat, cara, maupun objek investasinya. Dengan kata lain, bank syariah tidak mempunyai hak dan kebebasan sepenuhnya dalam menginvestasikan dana RIA ini ke berbagai sektor bisnis yang diperkirakan akan memperoleh keuntungan. ${ }^{30}$

\footnotetext{
${ }^{28}$ http://www.google.com/\#sclient=psy-ab\&q=tabungan + mudharabah\&oq=tabungan + mudharabah diakses pada tanggal 23 Juli 2013

${ }^{29}$ Adiwarman, Bank Islam, hal...304

${ }^{30}$ Ibid, hal...307
} 
Pemilik dana (shahibul maal) membatasi/memberi syarat kepada mudharib/pihak bank dalam mengelola dana seperti misalnya hanya untuk melakukan usaha/proyek di bidang tertentu, cara, waktu, dan tempat tertentu saja.

\section{Nisbah Bagi Hasil}

Nisbah adalah pembagian keuntungan yang ditetapkan pada awal terbentuknya akad yang terbentuk dalam persentasi yang disepakati oleh kedua belah pihak yakni pada pihak bank dan pihak nasabah. Nisbah bagi hasil merupakan faktor penting dalam menentukan bagi hasil di bank syariah, sebab aspek nisbah merupakan aspek yang disepakati bersama antara kedua belah pihak yang melakukan transaksi. ${ }^{31}$

Besarnya nisbah ditentukan berdasarkan kesepakatan masing-masing pihak yang berkontrak. Jadi, angka besaran nisbah ini muncul sebagai hasil tawar-menawar antara shahibul maal dengan mudharib. Dengan demikian, angka nisbah ini bervariasi, bisa 50:50, 60:40, 70:30, 80:20, bahkan 99:1. Namun para ahli fiqih sepakat bahwa nisbah 100:0 tidak diperbolehkan. ${ }^{32}$

Sistem bagi hasil merupakan sistem di mana dilakukan perjanjian atau ikatan bersama di dalam melakukan kegiata usaha. Di dalam kegiatan usaha diperjanjikan adanya pembagian hasil atas keuntungan yang akan didapat antara kedua belah pihak atau lebih. Bagi hasil dalam perbankan syariah merupakan ciri khusus yang ditawarkan kepada masyarakat, dan di dalam aturan syariah yang berkaitan dengan pembagian hasil usaha harus ditentukan terlebih dahulu pada awal terjadinya kontrak (akad). Besarnya penentuan porsi bagi hasil antara kedua belah pihak ditentukan sesuai kesepakatan bersama, dan dibuat dengan dasar kerelaan (an-taradhin) di masing-masing pihak tanpa adanya unsur paksaan. ${ }^{33}$

Jadi, dapat disimpulkan bahwa nisbah harus dinyatakan dalam bentuk persentase antara kedua belah pihak, bukan dinyatakan dalam nilai nominal Rupiah tertentu.

Perbankan syariah lebih mementingkan keadilan, karena dengan adanya sistem bagi hasil ini, nasabah tidak akan merasa dirugikan dengan mendepositokan di bank syariah karena hasil dari pengelolaan dana yang dilakukan oleh bank sebagai mudharib dibagikan sesuai dengan kesepakatan yang telah dilakukan dalam akad.

\section{Profit Sharing}

Sejak awal berdirinya perbankan syariah di Indonesia, tidak ada bank yang menggunakan prinsip profit sharing dalam perhitungan distribusi pendapatan. Hal ini disebabkan kurang kompetitifnya tingkat return kepada nasabah. Distribusi pendapatan pada prinsip profit sharing dihitung dari pendapatan bersih margin dan bagi hasil dari investasi dikurangi dengan biaya pengolahan dana. ${ }^{34}$

Jumlah pendapatan bank dari investasi yang diterima prinsip profit sharing dan revenue sharing diasumsikan sama. Untuk profit sharing, pendapatan harus dikurangi terlebih dahulu dengan biaya pengelola dana pihak ketiga. Diasumsikan bahwa persentase biaya pengolahan itu diperoleh dari sumber dana pihak ketiga dan kemudian dibandingkan dengan sumber dana total dalam perbankan syariah. Biaya yang ditanggung bersama diasumsikan berasal dari biaya

\footnotetext{
${ }^{31}$ Muhammad, Manajemen Dana Bank Syari'ah, Yogyakarta: Ekonesia, 2004, h..123

${ }^{32}$ Ibid, h..209

${ }^{33}$ Karim, Fiqih, h..20

${ }^{34}$ Muhammad Yusuf, Junaedi, Pengantar Ilmu Ekonomi dan Perbankan Syariah, Jakarta: Ganeca Press, 2006 , h..127
} 
administrasi, biaya personalia, dan biaya penyusutan. Jumlah pendapatan margin serta bagi hasil yang disetor ke bank merupakan jumlah keuntungan bersih penerima pembiayaan. ${ }^{35}$

Dalam sistem tersebut terdapat risiko atas kerugian yang sewaktu-waktu dapat ditimbulkan. Apabila terdapat kerugian finansial/materi, hanya pemilik modal yang menanggung kerugian tersebut. Selain itu pengelola dana hanya menanggung kerugian waktu dan tenaga dari apa yang telah diusahakannya, kecuali mudharib (pengelola dana) lalai dalam melaksanakan tugasnya. ${ }^{36}$

\section{Revenue Sharing}

Dasar perhitungan bagi hasil yang menggunakan revenue sharing adalah perhitungan bagi hasil yang didasarkan atas penjualan dan/atau pendapatan kotor atas usaha sebelum dikurangi biaya. Bagi hasil dalam revenue sharing dihitung dengan mengalikan nisbah yang telah disetujui dengan pendapatan bruto. ${ }^{37}$

Contoh berikut untuk mempermudah penjelasan.

Nisbah yang telah ditetapkan adalah $10 \%$ untuk bank dan $90 \%$ untuk nasabah. Dalam hal bank sebagai mudharib dan nasabah sebagai shahibul maal, bila bank syariah memperoleh pendapatan Rp. 10.000.000,- maka bagi hasil yang diterima oleh bank adalah Rp. 10\% x Rp. $10.000 .000,-=$ Rp. $1.000 .000,-$ dan bagi hasil yang diterima oleh nasabah sebesar Rp. $9.000 .000,-$

Pada umumnya bagi hasil terhadap investasi dana dari masyarakat menggunakan revenue sharing. ${ }^{38}$

Dari definisi diatas dapat disimpulkan bahwa arti revenue pada prinsip ekonomi dapat diartikan sebagai total penerimaan dari hasil usaha dalam kegiatan produksi, yang merupakan jumlah dari total pengeluaran atas barang ataupun jasa dikalikan dengan harga barang tersebut.

\section{Hasil Penelitian}

\subsection{Gambaran Umum PT BPRS Amanah ummah}

\section{Sejarah singkat PT BPRS Amanah Ummah}

Bank Pembiayaan Rakyat Syariah Amanah Ummah atau disingkat dengan BPRS Amanah Ummah adalah salah satu bank pembiayaan rakyat syariah yang tumbuh di Indonesia, khususnya wilayah Bogor Barat, yang beroperasi berdasarkan prinsip-prinsip syariah Islam. Bank ini bertujuan untuk menumbuhkan ekonomi masyarakat atas dasar syariah Islam, sebagaimana telah diatur dalam Undang-Undang Nomor 21 tahun 2008.

Sebagai bangsa yang mayoritas penduduknya beragama Islam, maka kehadiran bank syariah di Indonesia yang diyakini prinsip-prinsip dan operasionalnya sesuai dengan syariah Islamiyah adalah suatu kebutuhan sekaligus suatu keharusan. Hal ini didasarkan pada suatu keyakinan umat yang kuat bahwa ajaran Islam adalah ajaran yang tidak hanya mengatur masalah aqidah dan akhlaq juga mengatur ibadah dan muamalah dalam berbagai aspek kehidupan, termasuk kehidupan sosial-ekonomi. Akan tetapi dilihat dari realitas kehidupan masyarakatnya yang serba tertinggal, baik dilihat dari sisi ekonomi maupun yang lainnya tidak mencerminkan nilai-nilai syariah.

\footnotetext{
${ }^{35} \mathrm{Ibid}, \mathrm{h} . .128$

${ }^{36}$ Karim, Fiqih, h..21

${ }^{37}$ Ismail, Perbankan Syariah, h..98

${ }^{38}$ Ibid. h..99
} 
Keadaan ini menimbulkan keprihatinan seorang ulama dan cendekiawan muslim Bogor, yaitu K.H. Sholeh Iskandar (Alm), yang pada saat itu menjabat sebagai Ketua Badan Kerjasama Pondok Pesantren (BKSPP) Jawa Barat. Beliau mulai merintis pembentukan sebuah lembaga keuangan yang mampu menyentuh sekaligus menolong masyarakat muslim yang hidup di bawah garis kemiskinan. Dalam berbagai kesempatan beliau melontarkan gagasannya di hadapan sejumlah ulama dan cendekiawan muslim dan ternyata mendapatkan tanggapan dan dukungan yang positif. Selanjutnya pada awal Januari 1991 secara resmi beliau mengundang sejumlah ulama, cendekiawan dan pengusaha muslim untuk membicarakan pendirian lembaga keuangan yang beroperasi atas dasar syariah Islam.

Dari pertemuan itu tercapai kesepakatan bahwa sudah saatnya dibentuk lembaga keuangan yang beroperasi atas dasar syariah Islam yang nantinya dapat membantu masyarakat muslim khususnya pengusaha muslim yang berekonomi lemah. Mengingat pada saat itu belum ada peraturan resmi tentang lembaga keuangan Islam, maka dibentuk Lembaga Swadaya Masyarakat yang berupa gerakan simpan pinjam yang diberi nama Koperasi Ikhwanul Muslimin. Bersamaan dengan hasil evaluasi tersebut, pada pertengahan Januari 1991, pemrakarsa mendapatkan informasi bahwa di Indonesia khususnya di Jawa Barat telah lahir BPR yang beroperasi berdasarkan syariah.

Pada awal Februari 1991 dibentuk tim untuk menyusun proposal pendirian bank syariah, pada bulan Juli 1991 proposal diajukan ke Departemen Keuangan Republik Indonesia. Alhamdulillah pada tanggal 16 Desember 1991 terbit izin prinsip dari Departemen Keuangan Republik Indonesia, dan pada tanggal 18 Mei 1992 bertepatan dengan tanggal 02 Muharram $1413 \mathrm{H}$ terbit izin operasional usaha bank, akhirnya pada tanggal 11 Juli 1992 diadakan soft opening sekaligus mulai melakukan operasionalnya. Sedangkan peresmiannya dilaksanakan pada tanggal 8 Agustus 1992 oleh Bupati Kepala Daerah Tingkat II Kabupaten Bogor.yang saat itu dijabat oleh Eddi Yoso Martadipura. Dengan demikian BPRS Amanah Ummah lahir dan beroperasi dengan semangat (ghirah) keagamaan dan keinginan yang kuat untuk memperbaiki kehidupan ekonomi umat Islam. ${ }^{39}$

\section{Visi dan Misi PT BPRS Amanah Ummah}

Visi

Menjadi BPR Syariah pilihan ummat

Menjadi BPR Syariah yang Amanah dan Profesional

Misi

Membangun kualitas kehidupan ummat melalui perbankan syariah

Motto

Meraih laba - Menepis Riba - Mengundang Berkah

\section{Budaya perusahaan}

Pelayanan Cepat - Amanah dan Profesional ${ }^{40}$

\footnotetext{
${ }^{39}$ PT BPRS Amanah Ummah, Laporan Tahunan 2012, h..3-4

${ }^{40}$ Ibid, h.. 1
} 


\section{Produk Penghimpun Dana PT BPRS Amanah Ummah}

\section{1) Tabungan Wadi'ah Ummah}

Tabungan wadi'ah ummah adalah simpanan pihak ketiga pada bank, yang penarikannya hanya dapat dilakukan menurut syarat-syarat dan cara-cara tertentu. Produk tabungan yang ada di BPRS Amanah Ummah adalah tabungan wadi'ah dengan akad wadi'ah yadhamanah, berupa titipan nasabah kepada bank. Bank diberi wewenang untuk mengelola uang dari nasabah tersebut. Bila bank mendapatkan keuntungan, maka nasabah akan mendapat athoya/bonus dari keuntungan yang langsung dibukukan pada rekening tabungan penabung setiap bulan. Adapun besarnya bonus dibagi berdasarkan keuntungan yang didapat dan merupakan kebijakan bank.

\section{2) Tabungan Ummah}

Tabungan yang diperuntukkan bagi masyarakat umum, berbentuk tabungan biasa dengan setoran awal minimal Rp. 10.000,- dan untuk setoran selanjutnya minimal Rp. 10.000,Sedangkan untuk tabungan perusahaan / badan usaha, setoran awal minimal Rp. 100.000,dan setoran selanjutnya minimal Rp. 50.000,-. Tabungan ini dapat diambil kapan saja pada setiap jam kerja.

3) Tabungan Pelajar

Tabungan Pelajar adalah tabungan yang diperuntukkan bagi pelajar dan santri dengan setoran awal minimal Rp.10.000,- dan setoran selanjutnya minimal Rp. 5.000,Pengambilan dan penyetoran tabungan dapat dilakukan kapan saja pada setiap jam kerja.

4) Tabungan Mudharabah Haji dan Umroh (TAHAROH)

Tabungan Mudharabah adalah tabungan yang berfungsi untuk investasi dana bagi masyarakat yang akan melaksanakan ibadah haji dan umroh. Setoran awal tabungan haji dan umroh minimal Rp. 100.000,- dan setoran selanjutnya minimal sebesar Rp. 50.000,tabungan ini dapat diambil pada saat nasabah hendak membayar Biaya Perjalanan Ibadah Haji (BPIH) atau sesuai kesepakatan antara bank dengan nasabah. Nasabah akan mendapatkan bagi hasil sesuai dengan kesepakatan dengan bank.

5) Deposito Mudharabah

Deposito Mudharabah adalah simpanan berupa investasi tidak terikat pihak ketiga pada bank yang penarikannya hanya dapat dilakukan pada waktu tertentu berdasarkan perjanjian antara nasabah pemilik dana (shahibul maal) dengan bank (mudharib), jangka waktu tersebut adalah satu, tiga, enam dan dua belas bulan, dengan bagi hasil sesuai dengan nisbah yang telah disepakati.

\section{Sumber Pendapatan Perusahaan PT BPRS Amanah Ummah}

a. Mark-up atau margin keuntungan, adalah nilai selisih antara harga jual dan harga beli yang diperoleh dari produk-produknya yang menggunakan prinsip akad murabahah (jual-beli).

b. Nisbah bagi hasil, adalah bagian keuntungan yang diperoleh dari produk-produk pembiayaan usaha, modal kerja dan investasi yang berdasarkan prinsip mudharabah maupun musyarakah.

c. Pendapatan sewa, adalah pendapatan yang diperoleh dari produk-produk yang menggunakan akad ijarah (sewa).

d. Pendapatan operasional lainnya, adalah pendapatan yang diperoleh dari kegiatan operasional. $^{41}$

\footnotetext{
${ }^{41}$ PT BPRS Amanah Ummah, Laporan Tahun 2011
} 


\subsection{Analisis Penentuan Nisbah Bagi Hasil Deposito Mudharabah PT BPRS Amanah Ummah}

\section{Landasan/Rujukan Hukum Pembagian Nisbah Bagi Hasil}

Pada pelaksanaan pembagian nisbah bagi hasil dalam deposito mudharabah di PT BPRS Amanah Ummah berlandaskan pada Al-Qur'an surat An-Nisa ayat 29.

"Hai orang-orang yang beriman, janganlah kamu saling memakan harta sesamamu dengan jalan yang batil, kecuali dengan jalan perniagaan yang berlaku dengan suka sama-suka di antara kamu...."(QS. An-Nisa:29)

Dalam ayat tersebut dapat dilihat bahwa Allah melarang perniagaan dengan jalan bathil kecuali perniagaan yang berlaku atas suka sama suka. Jadi, terdapat kesepakatan di antara pelaku perniagaan tersebut. Bagi hasil di PT BPRS Amanah Ummah ini mengikuti peraturan BI (Bank Indonesia) dalam bentuk persentase, bukan dalam bentuk nominal dan adanya kesepakatan bagi hasil di antara nasabah dan bank.

\section{Penerapan Kesepakatan Nisbah Bagi Hasil antara Pihak Bank dengan Nasabah}

Seperti yang sudah diketahui bahwa nisbah adalah pembagian keuntungan yang ditetapkan pada awal terbentuknya akad yang terbentuk dalam persentasi yang disepakati oleh kedua belah pihak yakni pada pihak bank dan pihak nasabah. Nisbah bagi hasil merupakan faktor penting dalam menentukan bagi hasil di bank syariah, sebab aspek nisbah merupakan aspek yang disepakati bersama antara kedua belah pihak yang melakukan transaksi. ${ }^{42}$

Besarnya nisbah ditentukan berdasarkan kesepakatan masing-masing pihak yang berkontrak. Jadi, angka besaran nisbah ini muncul sebagai hasil tawar-menawar antara shahibul maal dengan mudharib. Dengan demikian, angka nisbah ini bervariasi, bisa 50:50, 60:40, 70:30, 80:20, bahkan 99:1. Namun para ahli fiqih sepakat bahwa nisbah 100:0 tidak diperbolehkan. ${ }^{43}$

Begitupun dalam pembagian hasil di PT BPRS Amanah Ummah terdapat kesepakatan antara nasabah dan bank. Tetapi sejauh ini di PT BPRS Amanah Ummah tidak terdapat tawarmenawar dalam pembagian hasil karena sebagian besar pihak nasabah sepakat dalam persentase pembagian hasil yang telah ditawarkan oleh pihak bank sehingga nasabah tidak menawar atas persentase bagi hasil tersebut. Menurut penulis, sebaiknya pihak bank memberikan tawaran dalam hal persentase bagi hasil dengan menjelaskan kepada nasabah bahwa persentase bagi hasil itu dapat ditawar oleh nasabah apabila persentase yang telah ditentukan bank itu dapat berubah tentunya sesuai dengan perhitungan yang tidak dapat merugikan salah satu pihak, baik pihak pemilik dana ataupun pihak pengelola dana.

Bagi hasil deposito mudharabah di PT BPRS Amanah Ummah ini mengalami naik turun sehingga menyebabkan perubahan bagi hasil antara nasabah dan bank. Jika nasabah tidak sepakat atas perubahan bagi hasil tersebut, maka deposito mudharabah tidak diperpanjang. Faktor yang mempengaruhi naik turunnya nisbah bagi hasil deposito mudharabah yaitu:

a. Angka pembagi meningkat jika jumlah pendeposit semakin banyak

b. Dipengaruhi faktor pendapatan.

\footnotetext{
${ }^{42}$ Muhammad, Manajemen Dana Bank Syari'ah, Yogyakarta: Ekonesia, 2004, h..123

${ }^{43}$ Ibid, h..209
} 
Rumus perhitungan nisbah bagi hasil di PT BPRS Amanah Ummah yaitu sebagai berikut:

Saldo rata-rata DPK (Dana Pihak Ketiga)

DPK (Dana Pihak Ketiga). ${ }^{44}$

\subsection{Analisis Produk Deposito Mudharabah PT BPRS Amanah Ummah}

\section{Karakteristik Produk Deposito Mudharabah}

Karakteristik deposito mudharabah PT BPRS Amanah Ummah yaitu sebagai berikut

a. Berdasarkan jangka waktu 1, 3, 6, 12 bulan

b. Dana dapat ditarik sesuai jatuh tempo. Tapi, ada beberapa sebab yang diperbolehkan untuk nasabah menarik dana depositonya apabila:

1) Karena meninggal dunia

2) Untuk biaya Rumah Sakit

3) Untuk biaya pendidikan

4) Untuk pelunasan utang pada PT BPRS Amanah Ummah

5) Karena musibah

PT BPRS Amanah Ummah tidak memberikan penalty rate atau denda kepada nasabah yang mencairkan dana depositonya sebelum jatuh tempo, tapi pihak bank meminta infak kepada nasabah tersebut sebesar Rp. 20.000,- dan tidak dimasukkan pada pendapatan bank tapi dimasukkan pada infak atau dana sosial.

c. Dari sisi keuntungan berdasarkan bagi hasil di mana nasabah memperoleh bagi hasil sesuai nisbah yang ditentukan.

Berikut ini adalah persentase nisbah untuk nasabah yang ditentukan oleh bank:

1) 1 bulan sebesar $49 \%$

2) 3 bulan sebesar $52 \%$

3) 6 bulan sebesar $56 \%$

4) 12 bulan sebesar $58 \%$

Dalam persentase nisbah tersebut dapat disimpulkan bahwa jangka waktu dapat mempengaruhi persentase nisbah yang didapatkan, yaitu semakin lama jangka waktu yang diambil oleh deposan maka semakin besar persentase nisbah yang didapatkan oleh deposan tersebut.

\section{Teknis dan Proses Pembukaan dan Pencairan Warkat Deposito Mudharabah}

\section{Teknis dan proses pembukaan warkat deposito mudharabah}

Dalam pembukaan rekening deposito harus mempunyai buku tabungan untuk over booking bagi hasil deposito. Apabila nasabah tidak membuka buku tabungan di PT BPRS Amanah Ummah, nasabah dapat membuka buku rekening di bank lain dan untuk over booking bagi hasil deposito tersebut dibebani biaya sebesar ketentuan pihak bank.

Dalam pembukaan rekening deposito mudharabah, setoran pertama untuk masing-masing bank berbeda sesuai dengan kebijakan yang berlaku. Untuk PT BPRS Amanah Ummah menetapkan setoran pertama minimal sebesar Rp. 1.000.000,- (satu juta rupiah).

Persyaratan administratif yang harus dipenuhi oleh nasabah yang ingin melakukan pembukaan deposito mudharabah di PT BPRS Amanah Ummah.

\footnotetext{
${ }^{44}$ Wawancara dengan staf bagian Deposito PT BPRS Amanah Ummah Bogor Yeni Mulyaningsih S.Sos, Tanggal 30 Juli 2013
} 
1) $1 \mathrm{Lembar}$ fotokopi $\mathrm{KTP} / \mathrm{SIM} /$ identitas lainnya yang masih berlaku

2) 1 Lembar fotokopi KTP/SIM /identitas lainnya yang masih berlaku untuk ahli waris 17 tahun ke atas atau sudah memiliki Kartu Identitas

3) Mengisi aplikasi deposito

a) Menyerahkan kartu identitas nasabah dan ahli waris nasabah, jika memungkinkan dengan kartu keluarga

b) Membayar biaya materai

c) Menyetorkan dana ke teller

d) Diproses dibagian deposito

e) Pengesahan warkat bilyet

Untuk menjadi deposan tentu harus mengisi ketentuan-ketentuan yang telah ditetapkan bank. Adapun mekanisme pembukaan deposito, syarat dan kondisi apa saja yang ada pada deposito mudharabah nampak sebagai berikut:

1) Calon nasabah datang langsung ke PT BPRS Amanah Ummah dan langsung menghubungi bagian pelayanan nasabah atau customer service.

2) Kemudian calon nasabah meminta bagian pelayanan nasabah untuk menjelaskan tentang hal-hal yang berkaitan dengan deposito mudharabah dan syarat-syarat apa saja yang harus dipenuhi oleh nasabah.

3) Setelah nasabah mendapatkan informasi dan penjelasan dari bagian pelayanan nasabah dan calon nasabah pun bersedia menjadi nasabah pada deposito mudharabah. Selanjutnya bagian pelayanan nasabah meminta calon nasabah untuk membaca, melengkapi dan menandatangani formulir yang telah disediakan PT BPRS Amanah Ummah.

4) Calon nasabah mengisi formulir yang berisikan antara lain:

Data Pribadi:

a) Nama

b) Nama gadis ibu kandung

c) Tempat/Tanggal lahir

d) Alamat sesuai KTP/SIM/Paspor

e) No. Telepon

f) No. KTP/SIM/Paspor

g) SIUP/AD/ART

h) NPWP

i) Jenis Kelamin

j) Agama

k) Status Pernikahan

1) Pendidikan Terakhir

m) Pekerjaan

n) Alamat Pekerjaan

o) No. Telepon

p) Jabatan

q) Pendapatan Perbulan

r) Golongan Nasabah

Sumber Dana:

a) Sumber Dana

b) Tujuan Transaksi

Pilihan Produk

a) Deposito

b) Nominal deposito 
c) Nisbah

d) Pemotongan Zakat/Infak

e) Pada saat jatuh tempo pokok

Ahli Waris

a) Nama

b) Alamat

c) Hubungan dengan Ahli Waris. ${ }^{45}$

5) Mengisi surat perjanjian dengan akad mudharabah di sini disebutkan bahwa pihak pertama adalah deposan dengan pihak kedua adalah dari bank syariah itu sendiri. Pada surat perjanjian ini harus dibubuhi materai agar mempunyai kekuatan hukum yang kuat.

6) Nasabah menyerahkan fotokopi identitas diri (KTP/SIM, Paspor) yang sah dan masih berlaku.

7) Nasabah membayar biaya materai

8) Nasabah menyetorkan dana ke teller

9) Setelah menyetorkan dana ke teller dan formulir diisi dengan lengkap, formulir tersebut diproses dibagian deposito untuk diperiksa dan diinput.

10) Selanjutnya pengesahan warkat bilyet

Setelah calon deposan menyelesaikan persyaratan administratif dan pengesahan warkat bilyet seperti yang telah disebutkan tersebut, maka secara otomatis menjadi deposan di PT BPRS Amanah Ummah dengan jangka waktu deposito mudharabah yang diminati oleh deposan tersebut, yaitu 1 bulan, 3 bulan, 6 bulan atau 12 bulan.

Dalam formulir deposito mudharabah di PT BPRS Amanah Ummah ini penulis dapat melihat adanya perbedaan deposito mudharabah dengan deposito konvensional bahwa dalam deposito mudharabah terdapat poin yang berisikan tentang ahli waris, di mana kegunaan ahli waris dalam deposito mudharabah ini yaitu untuk berjaga-jaga apabila ada hal yang tidak diinginkan terjadi pada deposan, misalkan apabila deposan meninggal dunia atau hal lain sebagainya maka ahli waris inilah yang dapat melakukan pencairan pada dana deposito mudharabah tersebut.

\section{Teknis dan proses pencairan deposito mudharabah}

Adapun proses pencairan deposito mudharabah ini adalah sebagai berikut:

1) Deposan harus membawa bukti diri bahwa dia memang memiliki deposito dengan membawa specimen deposito yang berfungsi untuk menyamakan tanda tangan nasabah yang akan melakukan pencairan dana tersebut.

2) Deposan harus mengisi aplikasi pengambilan deposito, untuk deposan yang melakukan pencairan dan tidak datang langsung ke bank dapat mencairkan dananya dengan instruksi pencairan melalui fax dan ketika deposan datang ke bank harus membawa SI (standing interaction) atau surat instruksi nasabah untuk mentransfer hasil.

3) Jika nasabah tidak melakukan pencairan pada jatuh tempo, maka dapat diperpanjang secara otomatis menggunakan sistem ARO (Automatic Roll Over) yaitu deposito akan diperpanjang otomatis setelah jatuh tempo, sampai pemiliknya mencairkan depositonya.

4) Deposan harus memberi materai diaplikasi pengambilan agar mempunyai kekuatan hukum bagi kedua belah pihak.

Di sini dapat dilihat bahwa pihak bank sangat berhati-hati terhadap deposan dalam melakukan pencairan karena ditakutkan adanya hal-hal yang tidak diinginkan seperti pencairan yang dilakukan bukan oleh deposian atau ahli waris. Maka setiap pencairan melalui fax harus disertakan dengan SI (standing interaction) yaitu surat instruksi nasabah untuk mentransfer hasil deposito dan disertakan dengan materai agar mempunyai kekuatan hukum bagi kedua belah pihak (pihak nasabah dan pihak bank).

\footnotetext{
${ }^{45}$ Aplikasi Permohonan Deposito PT BPRS Amanah Ummah
} 


\section{$5 \quad$ Kesimpulan dan Saran}

\section{Kesimpulan}

Berdasarkan pembahasan bab-bab sebelumnya mengenai produk penghimpunan dana Deposito mudharabah di PT BPRS Amanah Ummah, dapat ditarik kesimpulan sebagai berikut:

Implementasi sistem bagi hasil Mudharabah pada PT BPRS Amanah Ummah dengan produk deposito mudharabah di mana akad yang digunakan ialah akad mudharabah mutlaqah dengan setoran awal minimal Rp. 1.000.000,- dengan nisbah bagi hasil yang telah ditentukan di akad.

Analisis terhadap penentuan penentuan nisbah bagi hasil deposito mudharabah di PT BPRS Amanah Ummah mengikuti peraturan BI tetapi tidak mengikuti dalam pembagian hasil nominal. Ada dua faktor yang menyebabkan bagi hasil naik turun. Faktor pertama yang mempengaruhi naik turunnya nisbah deposito di antaranya angka pembagi meningkat karena jumlah pendeposit semakin banyak. Faktor kedua yaitu dipengaruhi faktor pendapatan. Sebagian besar bentuk mudharabah yang diterapkan pada deposito mudharabah ini adalah mudharabah mutlaqah maka dana deposito di PT BPRS Amanah Ummah disalurkan pada produk pembiayaan. Jika terdapat nasabah yang tidak ingin akad depositonya mudharabah mutlaqah maka dapat menggunakan akad mudharabah muqayyadah.

\section{Saran}

Meskipun dianggap cukup baik dalam pelaksanaan operasional produk deposito mudharabah, namun masih terdapat kelemahan yang harus diminimalisir. Setelah penulis melaksanakan penelitian, menganalisis, dan menyimpulkan, maka ada beberapa saran, di antaranya:.

1. Melakukan sosialisasi yang menarik agar banyak anggota masyarakat yang mendepositokan dananya, dengan cara membuat brosur khusus produk deposito mudharabah dengan mencantumkan kelebihan produk deposito mudharabah tersebut.

2. Dalam pembagian bagi hasil deposito mudharabah sebaiknya pihak bank memberikan penawaran persentase kepada nasabah meskipun nasabah setuju dengan persentase yang telah ditentukan oleh pihak bank.

3. Dalam pembukaan rekening deposito mudharabah sebaiknya pihak bank menjelaskan penyaluran dana yang akan dilakukan. Sehingga nasabah dapat memilih akad deposito mudharabah mutlaqah atau deposito mudharabah muqayyadah. Sehingga prinsip syariah mengenai pelaksanaan pembukaan rekening deposito mudharabah terlaksana seluruhnya. 


\section{Daftar Pustaka}

Antonio, Muhammad Syafi'i, Bank Syariah dari Teori ke Praktik, Jakarta: Gema Insani Press, 2001.

Al-Qur'an dan Terjemah, Jakarta: Pustaka Alfatih, 2009.

Fatwa Dewan Syariah Nasionaln No.03/DSN-MUI/IV/2000.

Heykal, Muhamad, Nurul Huda, Lembaga Keuangan Islam Tinjauan Teoritis dan Praktis,Jakarta: Kencana Prenada Media Group, 2010.

http://halal-ok.blogspot.com/2009/10/tinjauan-syariah-produk-deposito.html, diakses pada tanggal 10 Juni 2013.

http://www.google.com/\#sclient=psyab\&q=tabungan + mudharabah\&oq=tabungan + mudharabah diakses pada tanggal 23 juli 2013.

Ismail, Perbankan Syariah, Jakarta: Kencana Prenada Media Group, 2011.

Karim, Adiwarman A, Bank Islam dan Analisis fiqih dan Keuangan, Jakarta: PT Rajagrafindo Persada, 2004.

Karim, Helmi, Fiqih Muamalah Cet 2, Jakarta: PT Rajagrafindo Persada, 1997.

Kasmir, Dasar-Dasar Perbankan, Jakarta: PT Rajagrafindo Persada, 2002.

Laporan PPL Terstruktur Ekonomi Syariah UIKa di PT BPRS Amanah Ummah: UIKA, 2011.

Mirakhor, Zamir Iqbal Abbas, Pengantar Keuangan Islam Teori dan Praktek, Jakarta: Kencana Prenada Media Group, 2008.

Muhammad, Manajemen Dana Bank Syari'ah, Yogyakarta: Ekonesia, 2004.

Yusuf, Muhammad, Junaedi, Pengantar Ilmu Ekonomi dan Perbankan Syariah, Jakarta: Ganeca Press, 2006,

Nasution, Metodologi Research Penelitian Ilmiah, Jakarta: Bumi Aksara, 2003.

PT BPRS Amanah Ummah, Laporan Tahunan 2011.

PT BPRS Amanah Ummah, Laporan Tahunan 2012.

Sevilla, Consuelo G, Jesus A Ochave, Twila G.Punsalan, Bella P.regala, Gabriel G.Uriarte, Pengantar Metode Penelitian, Jakarta: Universitas Indonesia, 1993.

Shihab, M. Quraish, Wawasan Al-Qur'an: Tafsir Maudhu'i Atas Berbagai Persoalan Umat, Jakarta: Mizan, 1996.

Tanjung, Hendri, Metodologi Penelitian, Bogor: UIKA Press, 2012.

Undang-Undang Republik Indonesia No. 21 Tahun 2008 tentang Perbankan Syariah. 